\title{
SUSTAINING URBAN FORESTS
}

\section{by John F. Dwyer', David J. Nowak', and Mary Heather Noble ${ }^{3}$}

\begin{abstract}
The significance of the urban forest resource and the powerful forces for change in the urban environment make sustainability a critical issue in urban forest management. The diversity, connectedness, and dynamics of the urban forest establish the context for management that will determine the sustainability of forest structure, health, functions, and benefits. A dynamic planning and management model is presented that encourages decisions that will support sustainability through the implementation of collaborative and adaptive management.
\end{abstract}

Key Words. Urban forest; adaptive management; collaborative; sustainability; regeneration; tree systems; forest health.

A considerable amount of attention is being given to sustainable forest management in the United States and around the globe. Urban forest sustainability is a significant concern, given the importance of urban forests and the powerful physical, biological, and social forces for change that affect their sustainability. The purpose of this paper is to outline an approach to urban forest planning and management that will facilitate sustainable urban forest management. This approach is also likely to be useful in other situations where people-forest interactions are intense.

\section{THE IMPORTANCE OF THE URBAN FOREST}

The urban forest covers a large and expanding area. Approximately $3.5 \%$ of the United States is currently classified as urban (urban areas). Nearly $25 \%$ is either located in or functionally tied to urban areas (i.e., greater metropolitan areas) (Nowak et al. 2001). Urban and metropolitan areas have grown tremendously, with urban sprawl being a significant environmental concern of the 21st century. Between 1950 and 1990, metropolitan areas increased threefold, while between 1969 and 1994, urban areas doubled in size (Dwyer, Nowak et al. 2000). Substantial population growth outside urban and metropolitan areas continues to extend urban influences to forest resources across the landscape, particularly in places with considerable scenic and recreational value (McGranahan 1999; Stewart 2001).

Urban and metropolitan areas include substantial forest resources that have the potential for significantly improving the quality of the urban environment and the well-being of its residents. Across the United States, tree canopy cover in urban and metropolitan areas averages $27 \%$ and $33 \%$, respectively, approaching the national average tree cover of $33 \%$. With approximately 74.4 billion trees in metropolitan areas and 3.8 billion trees in urban areas, the magnitude of the urban forest resource should not be ignored (Dwyer, Nowak et al. 2000).

Urban forests can make a considerable difference in quality of life by directly influencing the daily lives of nearly $80 \%$ of the U.S. population. Further, what happens in urban areas can have a profound impact on urban forests and the extended exurban landscape. Considering the significance of the resource, urbanization and urban forests are likely to be especially significant in the 21st century (Dwyer, Childs et al. 2000). The increasing significance of urban influences across the United States calls for resource policy makers, planners, and managers at the national, regional, and local levels to bring cooperative attention to planning and management efforts to sustain urban forests.

\section{SUSTAINABILITY}

While the precise definition of sustainable forest management is not always agreed on, it usually encompasses considerations such as maintaining biodiversity, productivity, regenerative capacity, vitality, and the potential to fulfill relevant ecological, economic, and social functions (Wiersum 1995). In this paper, urban forest sustainability is defined in terms of maintaining healthy and functional vegetation and associated systems that provide long-term benefits desired by the community. This definition places a significant emphasis on the role of people who manage and use the urban forest in providing for its sustainability.

Urban forest sustainability is broad based and complex. These characteristics can be attributed, in part, to the diverse and dynamic character of urban forests and their environment. This dynamic character originates from the impact that people and their activities have on urban trees (e.g., planting, removal, pruning, land development, plant injury) (Nowak 1991). Wide-ranging activities of people are among the major forces for change in the health and character of the urban forest and ultimately determine its sustainability, more so than with any other forest resource (Nowak 1993).

Given the relatively slow growth rates and high values of urban trees, substantial losses can be associated with changes that eliminate large trees. Furthermore, it may take decades for newly planted trees to become large enough to make substantial contributions. The important contribu- 
tions of large trees include aesthetics, cleansing the air, retaining rainfall, providing shade, and providing symbolic community heritage values. In fact, it is the enduring nature of large trees in a rapidly changing urban environment that contributes to their high symbolic values and a sense of permanence in our fast-changing society.

While researchers and natural resource professionals seem to agree that the goal of management is to maintain forest benefits through space and time, there continues to be debate over the functional definition of urban forest sustainability (Wiersum 1995). Several attempts to characterize and model the components of sustainable urban forest systems have been made. Some researchers have even outlined specific criteria against which the sustainability of an ecosystem and its management may be measured (LeMaster and Sedjo 1993; Gangloff 1995; Clark et al. 1997). Because the social and ecological spheres of urban ecosystems are in constant flux, sustainability as a goal is subject to considerable variation. Ultimately, the attributes of a sustainable urban forest-what it looks like, how it functions, and how it is managed-depend on which ecological functions and social benefits are desired, who chooses them, and at what scale these elements are being sustained (Maser et al. 1994; Wiersum 1995; Gregersen et al. 1998). An approach to urban forest planning and management is presented that will lead to sustaining urban forest structure and health over time and space. This approach must be firmly grounded in the key characteristics of the urban forest.

\section{KEY CHARACTERISTICS OF THE URBAN FOREST}

Key characteristics of the urban forest that have significant implications for urban forest sustainability include its diversity, connectedness, and dynamics (Dwyer and Nowak 2000).

\section{Diversity}

Diversity is one of the most distinctive attributes of the urban forest. It is a function of variations in land uses, land ownerships, and management objectives. Multiple land uses and diverse populations characterize urban areas. The management of resources by several different groups creates a complex landscape pattern. This pattern includes a wide range of tree species and sizes, ground covers, soil types, microclimates, wildlife, people, buildings, and infrastructure. These elements are found in almost unlimited combinations. The mixture of natural and humanmade resources in urban ecosystems broadens the scope of urban forestry. The issues facing urban forest managers are wide ranging. They encompass such attributes as wildlife management; mitigating air pollution; enhancing aesthetic value; and providing recreation, flood control, and fire prevention.
Several factors serve as catalysts for increased urban forest diversity over time. Shifts in population, changes in economic activity, and improvements in transportation increase the range of land uses; broaden the spectrum of people involved; and complicate the mixture of old and new, artificial and natural, and the intermix of native and exotic resources.

\section{Connectedness}

Connectedness among its resource components in the urban environment is another key attribute of the urban forest. Urban forests are connected to other elements of urban environments, including roads, homes, people, industrial parks, and downtown centers. Connectedness may occur through the logistics of managing urban infrastructure, such as coordinating maintenance of urban trees and power lines, sewers, sidewalks, and roads. Urban forests also link "landscape" with "architecture" and become an important component of urban planning and design.

The connectedness of urban forests is also evident in their role in a wide range of urban issues. Urban forests and their management are often a part of programs for improving air and water quality, flood control, energy conservation, microclimate improvement, aesthetic enjoyment, recreational opportunities, urban renewal, and community revitalization (Dwyer et al. 1992).

Urban forests are also connected to the condition, use, and management of natural resources located outside urban areas (i.e., exurban). Management issues concerning wildlife, fires, insects, and diseases do not heed community boundaries and are shared among managers in both urban and rural environments. Further, many of the detrimental effects from urbanization (such as pollution, flooding, and acid rain) can affect the health of forests beyond the urban environment.

Finally, urban forests represent a critical link between people and forest resources. Use of residential holdings and forest preserves in urban areas provides opportunities for citizens to appreciate and learn about natural resources. The experiences that urban residents have with trees and associated resources in the urban environment are likely to influence their perceptions, expectations, and use of more distant natural resource areas, such as national forests, parks, and monuments.

\section{Dynamics}

Like all forests, urban forests undergo significant change with the growth, development, and succession of their biological components over time. However, the development of urban forest resources occurs in the context of much more powerful and rapid human-induced forces for change. Coupling the relatively slow biological processes with the swift human forces for change makes the management of the urban forest particularly complex and challenging. 
The expansion and development of urban areas over time bring important changes in vegetation and other resources. Alterations of land use plans and varying intensities of urbanization and population changes result in different combinations of and changes in (1) ground cover types (e.g., mixes of vegetation and artificial surfaces), (2) opportunities for tree establishment and growth, (3) environmental conditions, (4) resource-use patterns, and (5) management objectives. New developments in transportation and/or industry technologies can bring considerable change to the function and management of urban lands. Changes in neighborhood residents can also prompt different approaches to the management of forests in residential areas and open spaces. Further, the introduction of exotic plants and animals through transportation and trade can have profound influences on the urban forest, as evidenced by the introduction of kudzu, Dutch elm disease, gypsy moth, and the Asian longhorned beetle.

\section{CURRENT MANAGEMENT OF THE URBAN FOREST}

Traditional U.S urban forest management practices tend to focus on one component of the urban forest ecosystemtrees. These practices may ignore other components of the urban forest, such as other plants, animals, people, and infrastructure. Attention to the health of urban trees is a necessary, but not a sufficient, requirement for urban forest sustainability. If management activities are administered independently of community goals, they are not likely to represent the convergence of what is socially desirable and ecologically possible. Consequently, urban forest programs will not be sustained by community support. Some current urban forestry efforts are limited to planting trees in public places, particularly along streets and in parks. These areas account for only a small portion of the urban forest. Unless regional or comprehensive planning and mangement is conducted, management of these public areas will likely not be coordinated with actions on private lands.

\section{MANAGING URBAN FORESTS FOR SUSTAINABILITY}

Urban forest planning and management that encourages sustainability advocates the broadening of strategies from simply maintaining forest structure in a particular area to a communitywide effort. These efforts include exchange of information, prioritizing benefits, designing management objectives, coordinating management activities, reviewing outcomes, and evaluating progress. Given the diversity and connectedness of the urban forest resource, the following items are considered key elements of sustainable urban forest management.

\section{Recognize and Embrace Diversity and Complexity} The diversity and complexity of urban forest resources require management programs that draw from multiple disciplines. Among the fields that may be involved in urban forest management are forest and wildlife management; entomology and plant pathology; hydrology and soils; meteorology and atmospheric science; landscape architecture and recreation management; psychology and sociology; and economics and political science. Taking full advantage of how each of these disciplines can contribute to the management of urban forests is critical to the development of policies that are tailored to fit the wide range of urban environments.

\section{One-Size Management Does Not Fit All}

Given the unique character of urban forests found in particular settings, effective management requires differing forest management strategies within an urban environment (e.g., by land use, intensity of development) and among urban areas (e.g., different ecoregions and populations). With the complexity of land uses, a "one size fits all" urban forest management scheme is not appropriate for these diverse ecosystems. Managers should develop locally specific strategies to meet the needs of local populations within this regional context.

\section{Focus on the Human Dimensions}

What most distinguishes urban from exurban forests is the dynamic influence of people. Human activities not only change urban forest structure to meet functional needs, but they also try to minimize detrimental changes due to natural forces (e.g., insects and diseases). Given the inherently slow development of trees amid rapidly changing urban environments, human forces for change pose significant challenges for natural resources management in urban areas.

\section{Encourage Coordination Across Land, Users, and Ownerships}

A key element in managing urban forests in a regional context is the coordination of activities among different owners and managers across jurisdictions. The participation of multiple stakeholders in urban forest management is contingent on the creation of a forum to help link forest structures and their management throughout the urban system. Such collaborative stewardship involves not only owners, users, and managers but also includes those involved in the management of other urban components (e.g., city planners and residents). Partnerships among a wide range of decision makers who affect urban forest resources provide opportunities for those involved to identify common interests and resolve potential problems.

\section{Capitalize on Connections with Other Activities}

A combination of diverse human actions and natural forces will continue to shape urban forests in the years ahead. These forces highlight the need to coordinate urban forest resource management with many other urban activities. 
Some of these activiites include land use planning, environmental protection, residential development, infrastructure development and maintenance, community empowerment, and environmental education. These activities are highly likely to have a greater impact on the condition of the urban forest resource than all of the management activities that focus exclusively on maintaining urban vegetation.

\section{Implement Comprehensive Planning and Management}

The diversity of urban forest resources demand comprehensive approaches to their management. The complex relationships of urban forest components to air and water quality, wildlife habitat, and aesthetic character suggest that focusing management activities on only one component of the urban forest is likely to yield an unbalanced flow of important benefits (Neville 2000). Thus, it is important that a comprehensive ecosystem-based approach to management is adopted.

\section{Implement Adaptive Management}

Because urban forests are dynamic systems, their management must also be able to respond to rapid changes in the health and use of resources over time. Implicit in adaptive management of urban forests is the ability to monitor progress and evaluate the effectiveness of management decisions. To evaluate the effectiveness of management activities, management plans should include a means by which managers can review the outcomes of their efforts by (1) monitoring the effects of program activities, (2) identifying areas for improvement, and (3) modifying management plans to address problems. Adaptive management provides the flexibility necessary to sustain and enhance important forest resources in changing urban environments.

\section{IMPORTANT CHALLENGES TO MANAGEMENT FOR SUSTAINABILITY}

The desirability of planning and management efforts that will help sustain urban forest resources is clear. However, the implementation and operation of these activities pose some of the most difficult challenges facing urban forest managers. Several factors complicate the application of comprehensive and adaptive urban forest management. These factors include the diversity and fragmentation of the resource and its ownership; a lack of consistent natural resource information across the urban system; inadequate funding; and different types and levels of resource management across land uses and ownerships. Adaptive approaches are also constrained by limited knowledge of the objectives of urban landowners; how forest structure at the landscape level influences local and regional benefits; how urban forest resources have changed through time; and interest and willingness of landowners to participate in cooperative management programs. With these limitations, the narrow scope of many current urban forestry programs to simply maintain street trees or publicly owned vegetation is not surprising. Yet a focus on maintaining forest structure on public holdings does not encompass the entire urban forest. It does not address the complex and dynamic needs of urban residents or the sustainability of the urban forest resource and its contribution to social well-being. The following section outlines a planning and management model that can help managers move closer to long-term sustainability of the urban forest resource.

\section{A MODEL TO GUIDE URBAN FOREST PLANNING AND MANAGEMENT FOR SUSTAINABILITY}

In this section, a framework for guiding urban forest planning and management to achieve sustainability is presented. This framework is based on five interrelated factors (Dwyer, Nowak et al. 2000) (Figure 1):

1. Social context-The concerns, attitudes, and values of community residents, organizations, and government agencies.

2. Management goals and objectives_Urban forest benefits and functions that the community wishes to sustain.

3. Means-Specific vegetation structure and/or management programs that have been identified as necessary to sustain desired urban forest benefits.

4. Management outcomes-Urban forest structure, condition, and use resulting from management programs.

5. Information-Inventory data, statistics, survey results, and research providing information about the characteristics of the resource, the relationship between vegetation structure and benefits, management techniques, urban forest health, and monitoring technologies.

These five factors are connected through a process of urban forest planning and management (Figure 1). First, operating within the social context that encompasses and permeates all of urban forestry, interested individuals and groups interact with policy makers and managers to prioritize the urban forest benefits they want to sustain and to develop budgeting alternatives to obtain these benefits. As discussed earlier, having the community define socially desirable benefits is an essential component of building urban forest sustainability.

Working within the planning and management system, managers translate desired benefits into management goals that they can use to plan management actions. Next they implement the vegetation structure or urban forest management programs needed to sustain desired functions. In this process is a great deal of learning and adjusting as new management outcomes are sought and ongoing programs are evaluated. A large number of individuals and groups may be involved in this dynamic management/evaluation/ monitoring process. 


\section{Social Context}
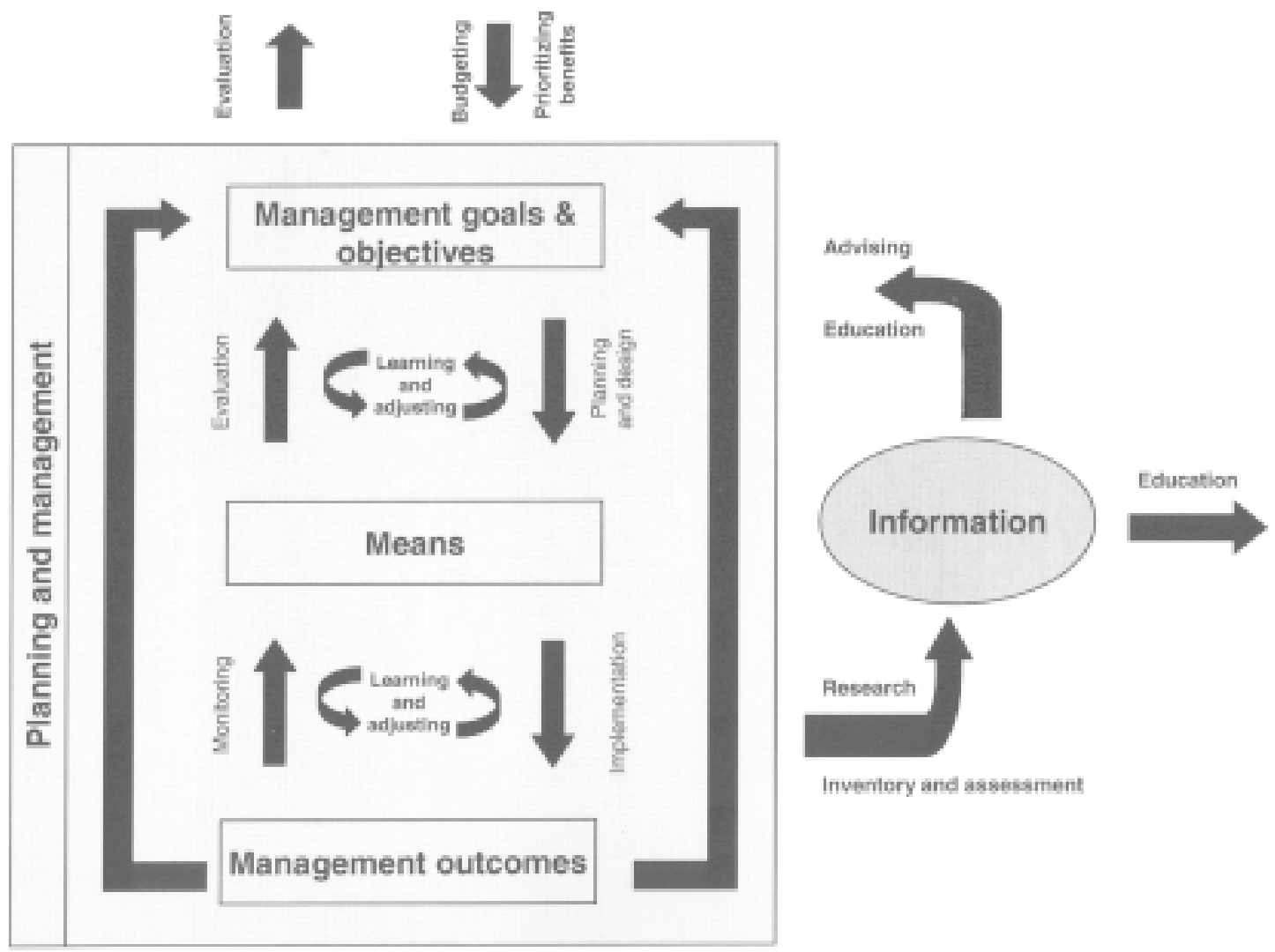

Figure 1. A model of sustainable urban forest planning and management.

The input of information about urban forest functions, benefits, health, and management techniques is constant throughout this process of setting goals and implementing and evaluating management activities. This information includes what is learned that is critical to the management and planning process. At times, the outcome resulting from management efforts may not resemble the structure or program needed to sustain desired urban forests. In these instances, people may need to work through several cycles of monitoring and adjusting management programs before their efforts produce the desired community.

The truly adaptive nature of the planning and management process lies in the continuing evaluation of management objectives. Without this step, the management cycle may continue without regard to shifting social paradigms or other important changes in the urban environment. Consequently, resources may be used to sustain urban forests that are no longer important to the community. Public desires may change as a result of many events, including experienc- ing the results of the management process. Their interest in some goals may diminish or heighten as they experience the management process. Without adapting to these potential changes, the urban forest management system will not be sustainable. In addition to testing structure-function relationship hypotheses, continuous evaluation of management objectives makes it necessary for managers to adapt their efforts to changes in the attitudes of the community. Thus, the human dimensions of urban forest sustainability are especially critical given the strong role that people's activities play in the sustainability of the urban forest.

The key to adaptive management is learning from the outcomes of management efforts and applying new information to the cycle (Lee 1993; Bormann et al. 1994; Maser et al. 1994; Gregersen et al. 1998). Periodic assessment of urban forest management programs and involved groups to assess change is crucial to the adaptive management method. 


\section{SUMMARY}

Urban forests are diverse and interconnected ecosystems. They are part of complex environments and are linked with many other components of the urban system. Management of urban forest systems requires the involvement of a widening range of disciplines, users, and managers to sustain forest health.

Current urban forest management often focuses on sustaining a healthy population of publicly owned trees. Expanding the management focus of urban forests to all trees and associated resources is required. The management of trees in the urban ecosystem will be challenging and will require nontraditional techniques. However, the overall societal benefits of doing so will be substantial.

The new approaches to urban forest management must be comprehensive and must be adaptive to allow for adjustments in management activities based on new information. To attain comprehensive and adaptive management, urban forest managers should consider:

- the needs and attitudes of the community.

- what urban forest structure is necessary to best address community needs.

- periodically reassessing community needs and urban forest structure to ensure that management plans remain appropriate.

As illustrated by the planning and management model (Figure 1), urban forest sustainability exists in a broad social context and is driven by a constant input of information. Research is needed to provide critical information for guiding comprehensive and adaptive management.

Urban forest planning and management as outlined here broadens some traditional perceptions of urban forestry from street- and park-tree care into a highly valued component of long-term sustainability. In developing management programs, the dynamics of urban forests must be considered. A comprehensive approach will encompass an array of management considerations, particularly social policies and programs. Social, political, and biological concerns must be jointly addressed to sustain urban forest health and structure in the 21 st century.

\section{LITERATURE CITED}

Bormann, B.T., P.G. Cunningham, M.H. Brookes, V.W. Manning, and M.W. Collopy. 1994. Adaptive ecosystem management in the Pacific Northwest. Gen. Tech. Rep. PNW-GTR-341. USDA Forest Service, Pacific Northwest Research Station, Portland, OR. 22 pp.

Clark, J.R., N.P. Matheny, G. Cross, and V. Wake. 1997. A model of urban forest sustainability. J. Arboric. 23(1):17-30.

Dwyer, J.F., and D.J. Nowak. 2000. A national assessment of the urban forest: An overview, pp 157-162. In Proceedings of the Society of American Foresters 1999
National Convention, 11-15 September 1999, Portland OR. Society of American Foresters, Bethesda, MD.

Dwyer, J.F., G.M. Childs, and D.J. Nowak. 2000. Forestry in urban and urbanizing areas of the United States: Connecting people with ecosystems in the 21st century, pp 629-637. In Krishnapillay, B., E. Soepadmo, N. Arshad, A. Wong, S. Appanah, S. Chik, N. Manakaran, H. Trong, and K. Choon (Eds.). Forests and Society: The Role of Research. Sub-Plenary Sessions Vol 1. XXI IUFRO World Congress, 7-12 August 2000, Kuala Lumpur, Malaysia.

Dwyer, J.F., E.G. McPherson, H.W. Schroeder, and R.A. Rowntree. 1992. Assessing the benefits and costs of the urban forest. J. Arboric.18(5):227-234.

Dwyer, J.F, D.J. Nowak, M.H. Noble, and S.M. Sisinni. 2000. Connecting people with ecosystems in the 21 st century: An assessment of our nation's urban forests. Gen. Tech. Rpt. PNW-GTR-490. USDA Forest Service, Pacific Northwest Research Station, Portland, OR. 493 pp.

Gangloff, D. 1995. The sustainable city. Am. For. May/ June:30-34, 38.

Gregerson, H., A. Lundgren, and N. Byron. 1998. Forestry for sustainable development: Making it happen. J. For. 96(3):6-10.

Lee, K.N. 1993. Compass and Gyroscope: Integrating Science and Politics for the Environment. Island Press, Washington, DC. 243 pp.

LeMaster, D., and R. Sedjo (Eds.). 1993. Modeling Sustainable Forest Ecosystems. Forest Policy Center, American Forests, Washington, DC.

McGranahan, D. 1999. Natural amenities drive rural population change. Agricultural Economic Report No. 781. USDA Economic Research Service, Washington, DC. 32 pp.

Maser, C., B.T. Bormann, M.H. Brookes, A.R. Keister, and J.R. Weisland. 1994. Sustainable forestry through adaptive ecosystem management is an open-minded experiment, pp 304-340. In Maser, C. (Ed.). Sustainable Forestry: Philosophy, Science, and Economics. St. Lucie Press, Delray Beach, FL.

Neville, L.R. 2000. Managing urban ecosystems, a look to the future of urban forestry, pp 411-424. In Kuser, J.E. (Ed.). Handbook of Urban and Community Forestry in the Northeast. Kluwer Academic/Plenum Publishers, New York, NY.

Nowak, D.J. 1991. Urban Forest Development and Structure: Analysis of Oakland, California. Ph.D. Dissertation, University of California, Berkeley. 232 pp.

_ 1993. Historical vegetation change in Oakland and its implications for urban forest management. J. Arboric. 19(5):313-319.

Nowak, D.J., M.H. Noble, S.M. Sisinni, and J.F. Dwyer. 2001. People and trees: Assessing the US urban forest resource. J. For. 99(3):37-42. 
Stewart, S.I. 2001. Amenity migration, pp 369-378. In Luft, K., and S. McDonald (Compilers). Trends 2000: Shaping the Future. Proceedings of the 5th Outdoor Recreation and Tourism Trends. 17-20 September 2000, Department of Park, Recreation, and Tourism Resources, Lansing, MI.

Wiersum, K.F. 1995. 200 years of sustainability in forestry: Lessons from history. J. Environ. Manage. 19(3):321-329.

Acknowledgments. We thank Pamela J. Jakes, USDA Forest Service, North Central Research Station, for her help in clarifying and presenting our model of sustainable urban forest planning and management, which is presented in Figure 1. The research on which this publication is based was funded, in part, by the USDA Forest Service's RPA Assessment Staff; and State and Private Forestry, Cooperative Forestry's Urban and Community Forestry Program.

\footnotetext{
${ }^{1 *}$ Research Forester/Project Leader

USDA Forest Service

North Central Research Station

1033 University Place, Suite 360

Evanston, IL 60201-3172, U.S.

jdwyer@fs.fed.us
}

\author{
${ }^{2}$ Research Forester/Project Leader \\ USDA Forest Service \\ Northeastern Research Station \\ 5 Moon Library \\ Syracuse, NY 13210, U.S. \\ dnowak@fs.fed.us
}

\section{${ }^{3}$ Geologist}

New Mexico Environmental Department

Ground Water Quality Bureau

1190 St. Francis Drive

P.O. Box 26110

Sante Fe, NM 87502, U.S.

mary_heather@nmenv.state.nm.us

${ }^{*}$ Corresponding author.
Résumé. La signification de la ressource forestière urbaine ainsi que les forces puissantes pour le changement dans l'environnement urbain font du soutien un aspect critique dans la gestion forestière urbaine. La diversité, les liens et les dynamiques de la forêt urbaine établissent le contexte de la gestion qui va déterminer le soutien à la structure de la forêt, sa santé, ses fonctions et ses bénéfices. Une planification dynamique et un modèle de gestion sont présentés afin d'encourager les décisions qui vont appeler un soutien à l'implantation d'une gestion coopérative et adaptée.

Zusammenfassung. Die Signifikanz urbaner Forstressourcen und die starken Kräfte zur Veränderung des urbanen Umfelds machen Selbsterhaltung zum kritischen Thema in der Verwaltung urbaner Forste. Die Vielfalt, Verbundenheit und Dynamik urbaner Forste bilden den Kontext für das Management, welches die Selbsterhaltung von Forststrukturen, -gesundheit, -funktion und -vorteilen bestimmt. Eine dynamisches Planungs- und Verwaltungsmodell, welches Entscheidungen unterstützt, wurde hier vorgestellt mit dem Ziel, Selbsterhaltung durch Kollaboration und adaptives Management zu unterstützen.

Resumen. El significado del recurso forestal urbano y las poderosas fuerzas para el cambio en el ambiente urbano hacen de la sustentabilidad un tema crítico en el manejo forestal urbano. La diversidad, la conectividad y las dinámicas de los bosques urbanos establecen el contexto para el manejo que determinará la sustentabilidad de la estructura, la salud, las funciones y los beneficios del bosque. Se presenta un modelo dinámico de planeación y manejo, que fomenta las decisiones que soportarán la sustentabilidad a través de la implementación de un manejo flexible y de colaboración. 